\title{
Bobot Lemak Abdominal Ayam Pedaging setelah Pemberian Teh Kombucha dalam Air Minum
}

\section{The Abdominal Fat Weight Of Broiler Chicken After The Consumption Of Kombucha Tea On The Drinking Water}

\author{
Rd. Yudhi Tresnadi Kusumah ${ }^{1}$ Sri Isdadiyanto ${ }^{2} *$ Sunarno $^{2}$ \\ ${ }^{1)}$ Program Studi Biologi, Departemen Biologi, Fakultas Sains dan Matematika, Universitas Diponegoro \\ ${ }^{2)}$ Departemen Biologi, Fakultas Sains Dan Matematika, Universitas Diponegoro \\ Jl. Prof. Soedarto, SH, Tembalang, Semarang \\ *Email: isdadiyanto@yahoo.com
}

Diterima 9 Maret 2017 / Disetujui 22 Agustus 2017

\begin{abstract}
ABSTRAK
Teh kombucha merupakan minuman hasil fermentasi teh dan gula oleh bakteri Acetobacter xylinum dan khamir Saccharomyces yang mengandung berbagai jenis asam organik dan vitamin, serta berperan sebagai probiotik. Peran teh kombucha sebagai growth promoter adalah dengan menyempurnakan proses metabolisme dalam pencernaan ayam pedaging, sehingga nutrisi dapat terserap dan tercukupi dengan baik untuk pertumbuhan dan perkembangan yang optimal. Tujuan dari penelitian ini adalah untuk menganalisis bobot lemak abdominal pada ayam pedaging (Gallus gallus) setelah pemberian teh kombucha dalam air minum. Penelitian ini dilaksanakan pada bulan September sampai Oktober 2014 di Laboratorium Biologi Struktur dan Fungsi Hewan. Teh kombucha yang digunakan merupakan hasil fermentasi teh hijau selama 12 hari. Hewan uji 20 ekor ayam pedaging strain CP 707 dibagi acak dalam 4 perlakuan konsentrasi yaitu, 0\%, 10\%, 20\%, dan $40 \%$ teh kombucha dalam air minum selama 32 hari. Analisa statistik menggunakan ANOVA pada taraf kepercayaan 95\% dan uji lanjut Duncan menunjukkan hasil tidak berbeda nyata terhadap lemak abdominal dan konsumsi pakan, sedangkan bobot tubuh dan konsumsi minum menunjukkan hasil berbeda nyata. Kesimpulan dari penelitian ini adalah pemberian teh kombucha dalam air minum sampai konsentrasi $40 \%$ belum mampu menurunkan kandungan lemak abdominal pada ayam pedaging.
\end{abstract}

\section{Kata kunci: teh kombucha, ayam pedaging, lemak abdominal}

\begin{abstract}
Kombucha tea beverage obtained by fermenting sweetened green tea for 12 days with Acetobacter xylinum and Saccharomyces which produced various kinds of organic acids, vitamins, and acts as a probiotic. Kombucha tea had a role as growth promoter was to enhance the metabolic processes in the digestive system of broiler, so that the nutrients could be absorbed and fulfilled properly for optimal growth and development. The research was conducted from September to October 2014 in the Laboratory of Biological Structure and Function, Diponegoro University. The objective of this research was to investigate the effects of kombucha tea on the drinking water to the abdominal fat weight. A total of 20 broiler chickens were randomly divided into 4 treatment concentrations $(0 \%, 10 \%, 20 \%$, and $40 \%$ of kombucha tea in drinking water) for 32 days. Statistical analysis using ANOVA at 0,05 significance level and Duncan's Multiple Range Test showed no significantly different results on abdominal fat and feed intake, while body weight and water intake showed significant results. It could be concluded from this study that the consumption of $40 \%$ kombucha tea concentration in drinking water, could not decreased abdominal fat.
\end{abstract}

Keywords: kombucha tea, broiler chicken, abdominal fat 


\section{PENDAHULUAN}

Tingginya kandungan lemak abdominal dan penurunan produktivitas pada ayam pedaging dapat diperbaiki dengan pemberian suplemen dalam pakan. Pemberian suplemen dalam pakan untuk menurunkan lemak abdominal dan meningkatkan produktivitas ayam pedaging pada prinsipnya adalah menjamin ketersediaan nutrien yang dibutuhkan untuk mengoptimalkan proses pencernaan, absorbsi nutrien, meningkatkan proses metabolisme, memacu pertumbuhan dan peningkatan produktivitas (Tana dan Djaelani, 2015).

Beberapa pilihan suplemen pakan baik yang organik atau non-organik telah dikenal oleh peternak ayam pedaging. Salah satu cara kerja suplemen pakan adalah menjamin $\mathrm{pH}$ optimum pada saluran pencernaan dan ketersediaan asam-asam organik esensial, seperti asam asetat, asam glukoronat, asam glukonat, asam laktat, asam oksalat, asam nikotinat, asam butirat, vitamin B1, B2, B6, B12 dan C serta mineral esensial $\mathrm{Cu}, \mathrm{Fe}, \mathrm{Mn}$, Ni dan $\mathrm{Zn}$ (Jayabalan et al., 2014). Beberapa nutrien esensial tersebut diduga dapat mengoptimalkan proses pencernaan, meningkatkan efisiensi metabolisme, meningkatkan nilai konversi pakan, produktivitas dan mencegah penimbunan lemak abdominal. Berbagai pilihan perlakuan suplemen pakan untuk penurunan lemak abdominal dan peningkatan produktivitas telah dilakukan oleh beberapa peneliti dan tersedia suplemen lainnya untuk diujicobakan.

Berbagai macam jenis asam lemak yang terdapat dalam teh kombucha mampu menurunkan kadar lemak abdominal. Mekanisme penurunan lemak abdominal oleh peran asam lemak (tidak jenuh) terjadi melalui peningkatan katabolisme lemak dan penurunan sintesis asam lemak endogen (Sanz et al., 1999). Bukti penelitian lainnya menyatakan bahwa pemberian asam lemak tidak jenuh sebanyak 3\% (metil linoleat) dari total pakan yang diberikan dapat menurunkan lemak abdominal mencapai 50\%, baik melalui mekanisme penghambatan lipogenesis, peningkatan oksidasi asam lemak oleh $\beta$-oksidasi atau keduanya (Sanz et al., 2000).

Kajian teh kombucha sebagai suplemen pakan untuk menurunkan lemak abdominal dan meningkatkan produktivitas pada ayam pedaging belum banyak dilakukan sehingga perlu diteliti. Teh kombucha merupakan minuman tradisional hasil fermentasi larutan teh dan gula yang telah dikenal masyarakat dan telah digunakan untuk memelihara kesehatan (Brady et al., 2000). Berdasarkan hal tersebut akan dilakukan penelitian dengan memanfaatkan teh kombucha sebagai suplemen pakan dan pengaruhnya terhadap penurunan bobot lemak abdominal.

\section{METODE PENELITIAN}

Penelitian dilakukan pada bulan JanuariFebruari 2015 di Laboratorium Biologi Struktur dan Fungsi, Departemen Biologi, Fakultas Sains dan Matematika, Universitas Diponegoro. Alat yang digunakan pada penelitian ini, yaitu wadah kaca volume 3 L, kain kassa, tali, botol, kulkas, kandang pemeliharaan sebanyak 24 buah, timbangan analitik, wadah kaca, gelas beker, gelas ukur, termometer, $\mathrm{pH}$ ukur, timbangan digital, higrometer, papan parafin dan dissecting set. Bahan yang digunakan pada penelitian ini, yaitu gula pasir, teh hijau, fermentasi teh kombucha, jamur kombucha, 24 ekor ayam (DOC), pakan ayam BR II, air minum (air bersih), vaksin (ND+IB) dan vitamin pertumbuhan ayam.

Penelitian ini merupakan jenis penelitian eksperimental dengan menggunakan Rancangan Acak Lengkap (RAL). Hewan uji yang digunakan pada penelitian ini adalah ayam broiler sebanyak 24 ekor (DOC). Ayam broiler tersebut dibagi dalam 4 perlakuan dengan 5 kali ulangan. Perlakuan diberikan berupa air minum atau larutan teh kombucha. Adapun 4 perlakuan tersebut adalah P0 yaitu air minum tanpa perlakuan, P1 yaitu $100 \mathrm{~mL}$ teh kombucha dilarutkan dalam $900 \mathrm{~mL}$ air (10\%), P2 yaitu $200 \mathrm{~mL}$ teh kombucha dilarutkan dalam $800 \mathrm{~mL}$ air (20\%) dan P3 yaitu $400 \mathrm{~mL}$ teh kombucha dilarutkan dalam $600 \mathrm{~mL}$ air (40\%).

Variabel utama yang diukur adalah kandungan lemak abdominal. Data yang diperoleh berasal dari Rancangan Acak Lengkap. Analisis dan pengolahan data dilakukan dengan analisis ANOVA pada taraf kepercayaan $95 \%(\alpha=0,05)$, kemudian dilanjutkan uji Duncan. Pengolahan data dilakukan dengan bantuan perangkat software SPSS versi 17.0. 


\section{HASIL DAN PEMBAHASAN}

Tabel 1. Hasil analisa statistik rata-rata konsumsi pakan, konsumsi minum, bobot tubuh, dan lemak abdominal ayam pedaging setelah pemberian teh kombucha.

\begin{tabular}{lcccc}
\hline Variabel & \multicolumn{1}{c}{ P0 } & P1 & P2 & P3 \\
& $\mathrm{X} \pm \mathrm{SD}$ & $\mathrm{X} \pm \mathrm{SD}$ & $\mathrm{X} \pm \mathrm{SD}$ & $\mathrm{X} \pm \mathrm{SD}$ \\
\hline $\begin{array}{l}\text { Lemak } \\
\text { abdominal (g) }\end{array}$ & $16,26^{\mathrm{a}} \pm 5,73$ & $16,33^{\mathrm{a}} \pm 8,66$ & $18,78^{\mathrm{a}} \pm 7,87$ & $16,32^{\mathrm{a}} \pm 6,31$ \\
$\begin{array}{l}\text { Bobot } \\
\text { tubuh (g) }\end{array}$ & $1318^{\mathrm{a}} \pm 65,34$ & $1240^{\mathrm{ab}} \pm 130,38$ & $1175^{\mathrm{ab}} \pm 115,61$ & $1076^{\mathrm{b}} \pm 127,78$ \\
$\begin{array}{l}\text { Konsumsi pakan } \\
\text { (g) }\end{array}$ & $3160^{\mathrm{a}} \pm 487,85$ & $3322^{\mathrm{a}} \pm 457,84$ & $3640^{\mathrm{a}} \pm 160,83$ & $2984^{\mathrm{a}} \pm 556,66$ \\
$\begin{array}{l}\text { Konsumsi minum } \\
(\mathrm{mL})\end{array}$ & $6119,80^{\mathrm{a}} \pm 253,32$ & $5386,80^{\mathrm{b}} \pm 319,28$ & $5452,50^{\mathrm{b}} \pm 175,19$ & $4860,60^{\mathrm{c}} \pm 161,49$
\end{tabular}

Keterangan : Superskrip yang berbeda pada baris yang sama menunjukkan perbedaan yang nyata antar perlakuan. P0 = kontrol, tanpa tambahan teh kombucha, P1 = air minum $+10 \%$ teh kombucha, $\mathrm{P} 2=$ air minum $+20 \%$ teh kombucha, $\mathrm{P} 3=$ air minum $+40 \%$ teh kombucha.

Uji Duncan pada signifikansi 5\% menunjukkan bahwa kandungan lemak abdominal pada ayam pedaging antara P0, P1, P2 dan P3 tidak berbeda nyata (Tabel 1). Hasil penelitian ini memberi bukti bahwa pemberian teh kombucha dengan konsentrasi $10 \%-40 \%$ tidak memberi pengaruh nyata terhadap penurunan lemak abdominal pada ayam pedaging. Hasil ini menunjukkan bahwa teh kombucha pada kisaran konsentrasi tersebut tidak mampu menurunkan kandungan lemak abdominal. Hal ini dimungkinkan berbagai macam asam lemak tidak jenuh dalam teh kombucha tidak mampu menurunkan lipogenesis dan meningkatkan katabolisme asam lemak yang dikatalisis oleh enzim $\beta$-oksidase. Kondisi ini bisa disebabkan karena kandungan asam lemak tidak jenuh dalam teh kombucha yang rendah atau konsentrasi teh kombucha yang rendah.

Hasil uji Duncan dengan signifikansi 5\% menunjukkan bahwa bobot tubuh ayam pedaging antara P0, P1 dan P2 tidak berbeda nyata. Bukti penelitian ini menunjukkan bahwa konsentrasi teh kombucha dalam air minum belum berpengaruh secara optimal terhadap bobot tubuh ayam pedaging. Diduga ada variabel lain yang memberi pengaruh dominan terhadap bobot tubuh selain perlakuan, seperti ketersediaan protein dalam pakan. Khumaini dkk. (2012) menyatakan pakan dengan kandungan protein 21-23\% memberi pengaruh terhadap bobot tubuh ayam pedaging yang tidak berbeda nyata. Hal ini disebabkan protein dengan kandungan tersebut memberi pengaruh dominan terhadap pertumbuhan ayam pedaging, khususnya pada masa starter dan grower. Kondisi ini akhirnya berpengaruh pada bobot tubuh ayam pedaging yang tidak berbeda nyata antara $\mathrm{P} 0$ dengan $\mathrm{P} 1$ dan $\mathrm{P} 2$.

Hasil lain menunjukkan bahwa bobot tubuh ayam pedaging berbeda nyata antara $\mathrm{P} 3$ dengan $\mathrm{P} 0$, namun tidak berbeda nyata dengan P1 dan P2. Bukti penelitan ini menunjukkan bahwa pemberian teh kombucha dalam air minum dengan konsentrasi $40 \%$ bobot tubuh ayam lebih rendah dibanding kontrol dan perlakuan lainnya (Gambar 2). Bukti ini sejalan dengan hasil penelitian Kusnandar (2004) yang menyatakan bahwa ayam pedaging dengan perlakuan teh kombucha $25 \%$ dalam air minum pada umur 7 sampai 35 hari memiliki bobot tubuh yang lebih rendah dibanding ayam tanpa perlakuan teh kombucha. Hal ini menunjukkan bahwa pemberian teh kombucha dengan konsentrasi $40 \%$ akan memberikan reaksi negatif terhadap pertumbuhan dan produktivitas ayam pedaging (ketersediaan 
nutrien dan produksi energi yang rendah) yang dibuktikan dengan bobot tubuh yang lebih rendah dibanding kontrol dan perlakuan lainnya. Hal ini sesuai dengan hasil penelitian Berdanier et al. (2014) yang menyatakan bahwa bobot tubuh ayam pedaging yang rendah disebabkan oleh terganggunya proses petumbuhan dan perkembangan sebagai akibat rendahya ketersediaan nutrien dan produksi energi hasil metabolisme. Rasyaf (2004) menyatakan bahwa bobot tubuh ayam yang rendah memiliki keterkaitan erat dengan kurangnya ketersediaan nutrien dan energi yang digunakan untuk memenuhi kebutuhan pokok, membentuk selsel jaringan tubuh, menggantikan bagian yang rusak, serta untuk kebutuhan produksi.

Teh kombucha mengandung asam-asam organik yang berperan sebagai acidifier, menciptakan suasana asam pada saluran pencernaan yang bertujuan untuk meningkatkan efisiensi penyerapan nutrien, namun kondisi yang terlalu asam diduga dapat menghambat kinerja enzim yang optimal pada suasana basa. Suhara (2010) menyatakan bahwa enzim peka terhadap perubahan $\mathrm{pH}$ dan memiliki suasana $\mathrm{pH}$ optimalnya masingmasing. Penghambatan kinerja enzim sebagai katalisator akibat suasana $\mathrm{pH}$ yang tidak sesuai beresiko menurunkan absorbsi nutrien yang dibutuhkan untuk keperluan pertumbuhan dan pembentukan jaringan tubuh. Bukti lain menyatakan, $\mathrm{pH}$ darah yang terlalu asam berakibat terhadap penurunan afinitas $\mathrm{Hb}$ dalam mengikat oksigen yang pada akhirnya akan terjadi penurunan metabolisme dan energi yang dihasilkan. Energi yang rendah berakibat pada penurunan produktivitas yang tercermin pada penurunan bobot tubuh seperti yang ditunjukkan pada bukti penelitian ini.

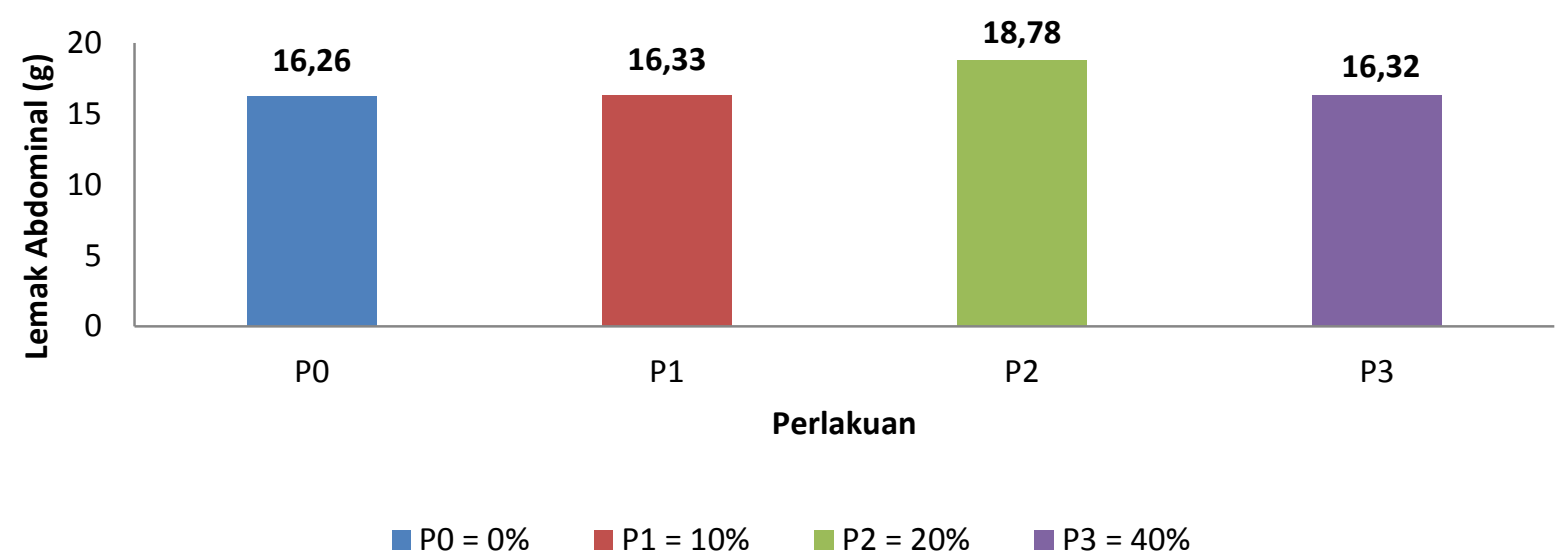

Gambar 1. Histogram rata-rata lemak abdominal pada setiap perlakuan.

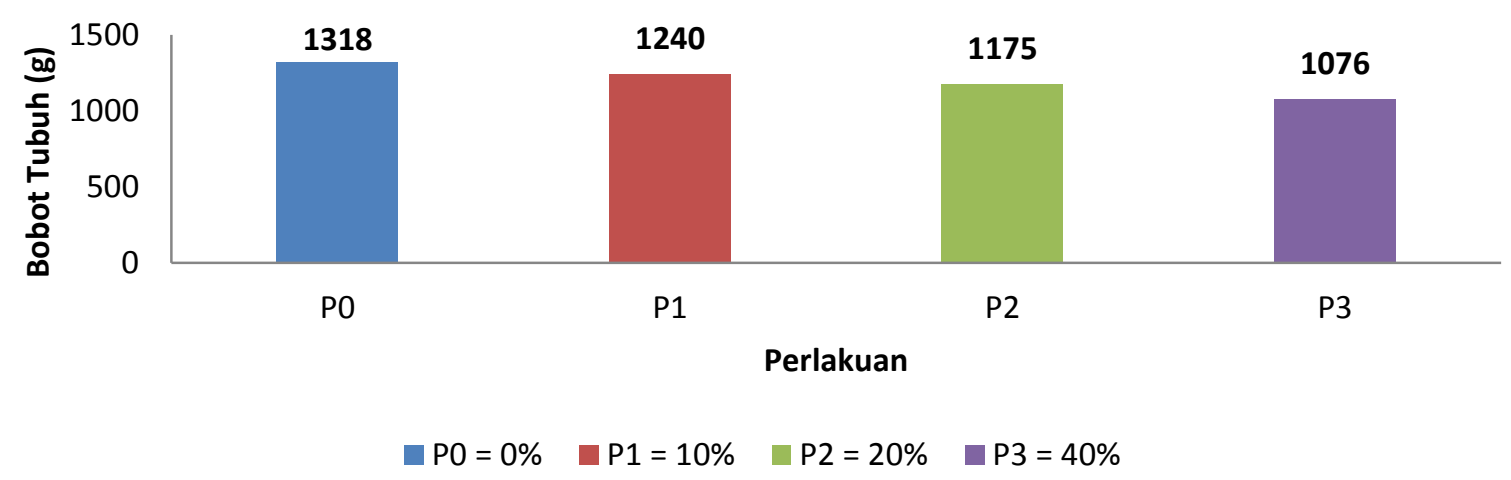

Gambar 2. Histogram rata-rata bobot tubuh ayam pedaging pada setiap perlakuan 
Hasil uji Duncan dengan signifikansi 5\% menunjukkan bahwa konsumsi pakan tidak berbeda nyata antara kontrol (P0) dengan perlakuan lainnya yaitu P1, P2 dan P3 (Gambar 3). Hal ini menunjukkan bahwa pemberian teh kombucha dalam air minum tidak mempengaruhi konsumsi pakan pada ayam pedaging. Rata-rata konsumsi pakan ayam pedaging per hari pada penelitian ini ialah 3277 g/ekor. Konsumsi pakan yang tidak berbeda nyata antar perlakuan berarti bahwa setiap ayam pedaging memiliki palatabilitas yang sama, sehingga pakan yang dikonsumsi relatif sama. Bukti penelitian ini menunjukkan bahwa konsumsi pakan berkaitan erat dengan palatabilitas yang diduga dipengaruhi oleh sinyal kimiawi bukan sebagai akibat dari perlakuan teh kombucha dalam air minum. Bebagai macam sinyal kimiawi dalam saluran pencernaan akan mempengaruhi reseptor yang terdapat pada sel-sel di tempat tersebut. Melalui pemrosesan yang terjadi pada serabut saraf sensoris, sistem saraf pusat dan serabut motoris akhirnya memicu nafsu makan (palatabilitas) dan perilaku makan yang memberi pengaruh pada konsumsi pakan.

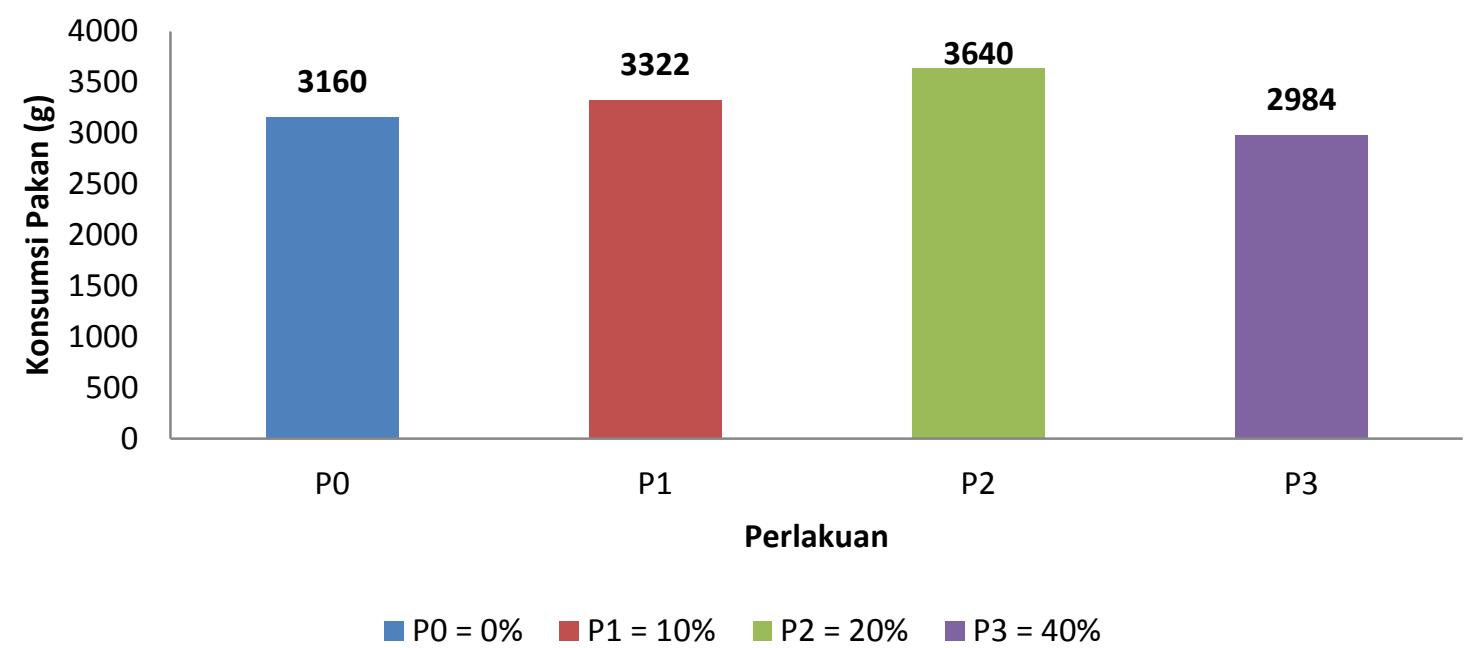

Gambar 3. Histogram rata-rata konsumsi pakan pada setiap perlakuan

Konsumsi air minum ayam pedaging berdasarkan hasil uji Duncan dengan signifikansi 5\% menunjukkan bahwa pemberian teh kombucha dalam air minum memberi perbedaan yang nyata terhadap konsumsi air minum ayam pedaging. Variabel ini tampak berbeda nyata antara kontrol dengan perlakuan lainnya (P1, P2 dan P3). Konsumsi air minum ayam pedaging menunjukkan perbedaan yang nyata antara $\mathrm{P} 3$ dengan $\mathrm{P} 1$ dan $\mathrm{P} 2$, dan tidak berbeda nyata antara P1 dengan P2. Bukti penelitian ini menunjukkan bahwa peningkatan konsentrasi teh kombucha dalam air minum memberi pengaruh terhadap penurunan konsumsi air minum ayam pedaging. Konsumsi air minum terendah terdapat pada perlakuan P3, yaitu rata-rata 4860,60 mL/hari (Gambar 4).

Pemberian teh kombucha dengan konsentrasi $40 \%$ konsumsi air minum lebih rendah dibandingkan kontrol dan perlakuan lainnya diduga akibat rasa asam dalam teh kombucha. Semakin tinggi konsentrasi teh kombucha semakin banyak kandungan asam-asam organik sehingga berpengaruh terhadap penurunan palatabilitas konsumsi air minum ayam pedaging (Tana dan Djaelani, 2015). Palatabilitas merupakan faktor yang sangat penting untuk menentukan tingkat konsumsi air minum pada ayam (Parakkasi, 1990). Palatabilitas ditentukan oleh sistem perasa gustative of taste buds ayam yang berada pada bagian belakang atap rongga mulut dan pada lidah (Tabler, 2012), dan dipengaruhi oleh rasa, tekstur, bau, dan akibat yang dirasakan setelah mengonsumsi air minum (Amrullah, 2004). Hasil penelitian ini memberi bukti bahwa konsentrasi teh kombucha yang tinggi dapat menggangu sistem perasa pada ayam pedaging yang berakibat pada penurunan palatabilitas dan air minum yang dikonsumsi. Konsumsi air minum ayam pedaging yang menurun merupakan bentuk adaptasi fisiologis untuk menyeimbangkan energi dalam tubuh (Amrullah, 
2004). Air minum yang banyak mengandung sumber energi akan dikonsumsi lebih sedikit dibanding air minum yang mengandung sumber energi lebih rendah. Hal ini sesuai bukti hasil penelitian ini. Hasil penelitian Akhadiarto (2005) menunjukkan, ayam pedaging yang diberi air minum dengan kandungan energi yang bervariasi, ayam pedaging lebih sedikit mengonsumsi air minum yang memiliki kandungan energi tinggi dan demikian sebaliknya.

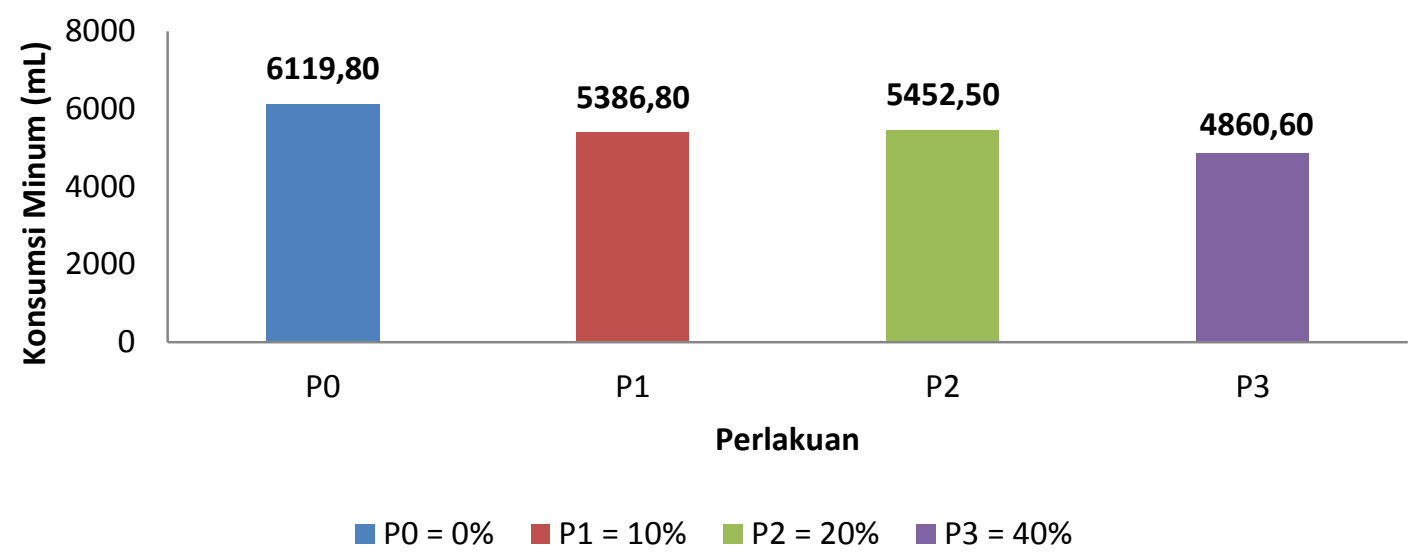

Gambar 4. Histogram rata-rata konsumsi air minum pada setiap perlakuan.

Hasil analisa statistik pada Tabel 1, baik variabel utama atau pendukung menunjukkan bahwa pemberian teh kombucha dalam air minum dengan konsentrasi $40 \%$ menyebabkan lebih rendah dibandingkan kontrol dan perlakuan lainnya. Hal tersebut mengakibatkan bobot tubuh ayam pedaging yang diberi teh kombucha dengan konsentrasi $40 \%$ pun menjadi lebih rendah dibndingkan kontrol dan perlakuan lainnya. Ayam pedaging pada perlakuan P3 setelah pemberian teh kombucha dengan konsentrasi $40 \%$ memiliki rata-rata konsumsi air minum terendah, yaitu $4860,60 \mathrm{~mL} / \mathrm{hari}$ dengan bobot tubuh akhir $1076 \mathrm{~g}$ yang merupakan bobot terendah. Bukti konsumsi air minum ayam pedaging pada penelitian ini lebih rendah dibanding hasil penelitian Suprijatna (2005) yang menyatakan bahwa konsumsi air minum ayam pedaging sebanyak 6514,74 mL/hari. Hal ini menunjukkan bahwa konsumsi air minum ayam pedaging berada dibawah rata-rata konsumsi yang seharusnya, sehingga beresiko mengganggu proses metabolisme dalam tubuh. Lacy (2002) menyatakan bahwa air berperan penting dalam reaksi metabolisme, memelihara temperatur tubuh, pencernaan makanan, dan pembuangan limbah, sehingga kekurangan air akan menghambat pertumbuhan dan perkembangan tubuh ayam pedaging. Terhambatnya pertumbuhan dan perkembangan akan berpengaruh terhadap penurunan bobot tubuh seperti bukti pada penelitian ini, dimana ayam pedaging pada perlakuan P3 memiliki rata-rata bobot tubuh akhir 1076 g/ekor yang berbeda nyata denga kontrol.

Rasyaf (2008) menyatakan bahwa bobot tubuh ayam pedaging dipengaruhi oleh kualitas dan kuantitas pakan yang dikonsumsi, sehingga kandungan nilai gizi yang seimbang diperlukan untuk pertumbuhan yang optimal. Ardana (2009) menyatakan bahwa air minum merupakan nutrien yang esensial pada ayam pedaging, tidak hanya berfungsi sebagai nutrien, tetapi air juga merupakan komponen utama darah sebagai alat transportasi dalam tubuh ayam pedaging, berfungsi untuk memperlunak pakan, membantu dalam proses pencernaan dan penyerapan nutrien lainnya serta sebagai penyeimbang dalam tubuh. Konsumsi pakan yang sama namun konsumsi air minum yang berbeda seperti hasil penelitian ini akan berpengaruh terhadap hambatan dalam proses pencernaan, penyerapan, penurunan metabolisme produk energi, pertumbuhan dan perkembangan sehingga pada akhirnya akan mempengaruhi penurunan bobot tubuh ayam pedaging.

Hasil penelitian ini juga memberi bukti bahwa ayam pedaging pada kontrol dan perlakuan dengan 
pemberian teh kombucha dalam air minum tidak menunjukkan perbedaan pada variabel konsumsi pakan dan lemak abdominal. Hal ini diduga bahwa nutrien yang bersumber dari pakan (konsumsi yang tidak berbeda nyata antara kontrol dengan perlakuan) akan mengalami deposisi yang sama, terutama pada jaringan lemak di bagian abdominal. Deposisi lemak dibagian abdominal dengan biomassa yang sama antara kontrol dengan perlakuan menguatkan bukti hasil penelitian ini. Sanz et al. (2000) menyatakan bahwa penimbunan lemak abdominal memiliki keterkaitan erat dengan laju anabolisme lemak jenuh atau sintesis asam lemak endogen atau melalui kedua proses tersebut. Ketika kedua proses tersebut memiliki laju yang relatif sama di dalam tubuh ayam pedaging, seperti pada perlakuan kontrol dan pemberian teh kombucha dalam air minum (P1, P2 dan P3) maka akan memberi pengaruh terhadap kandungan lemak abdominal ayam pedaging yang tidak berbeda nyata.

\section{KESIMPULAN}

Pemberian teh kombucha dalam air minum sampai konsentrasi $40 \%$ tidak menurunkan kandungan lemak abdominal pada ayam pedaging. Melihat bukti dari variabel pendukung yaitu bahwa pemberian teh kombucha dalam air minum dengan konsentrasi $40 \%$ mampu meningkatkan secara nyata konsumsi air minum dan penurunan bobot tubuh perlu dilakukan penelitian lanjutan tentang penambahan konsentrasi teh kombucha dan potensinya dalam menurunkan kandungan lemak abdominal pada ayam pedaging.

\section{DAFTAR PUSTAKA}

Akhadiarto, S. 2005. Pengaruh Pemberian Teh Fermentasi Kombucha pada Air Minum Terhadap Pertumbuhan Itik Tegal. J.Indon.Trop.Anim.Agric. 30(3). 162-166.

Amrullah, I. 2004. Nutrien Ayam Broiler. Lembaga Satu Gunung Budi. Bogor.

Anggorodi, R. 2001. Ilmu Makanan Ternak Umum. Gramedia. Jakarta.
Ardana, I. 2009. Ternak Broiler, Manajemen Produksi dan Penyakit. Penerbit Swasta Nulus. Denpasar.

Bauer, P. B and P. L. Tozi. 2000. Mineral and Water-soluble Vitamin Contents in The Kombucha Drink. Int. J. Food Sci. Technol. $35: 201-5$

Berdanier, C. D., Dwyer, J. T and D. Heber. 2014. Handbook of Nutrition and Food Third Edition. CRC Press. New York.

Brady, L. J., Gallaher, D. D and F. Busta. 2000. The Role of Probiotic Cultures in The Prevention of Colon Cancer. J. Nutr. 130: 410S - 414S.

Jayabalan, R., Radomir V. M., Eva, S. L., Jasmina, S. V and S. Muthuswamy. 2014. A Review on Kombucha Tea-Microbiology, Composition, Fermentation, Beneficial Effects, Toxicity, and Tea Fungus. Comprehensive Reviews in Food Science and Food Safety. Vol.13. pp. 538-550

Khumaini, A., Mudawaroch, R. E and D. A. Hanung. 2012. Pengaruh Penambahan Teh Kombucha dalam Air Minum Terhadap Konsumsi Pakan dan Konsumsi Air Minum Ayam Broiler. Surya Agritama. Vol. 1, No. 2. Hlm. 85-93.

Lacy, M. 2002. Broiler Management.: Commercial Chicken Meat and Egg Production. Kluwer Academic Pub. Norwell, MA.

Parakkasi, A. 1990. Ilmu Gizi dan Makanan Ternak Monogastrik. Angkasa. Bandung.

Rasyaf, M. 2004. Makanan Ayam Broiler. Kanisius. Yogyakarta.

Sanz, M., Flores, A., Perez De Ayala, P and C. Lopez-Bote. 1999. Higher lipid accumulation in broilers fed saturated fats than in those fed unsaturated fats. Br. Poult. Sci. 40: 95-101.

Sanz, M., Flores, A and C. Lopez-Bote. 2000. The metabolic use of calories from dietary fat in broilers is affected by fatty acid saturation. $\mathrm{Br}$. Poult. Sci. 41: 61-68.

Suhara. 2010. Dasar-dasar Biokimia. Prisma Press. Bandung. 
Suprijatna, E. 2005. Ilmu Dasar Ternak Unggas.

Penebar Swadaya, Jakarta.

Tabler, T., Jessica, W and Z. Wei. 2012. WaterRelated Factors in Broiler Production. Mississippi State University Extension Service.

Tana, S dan M. A. Djaelani. 2015. Kadar Kolesterol Daging Ayam Broiler Setelah Pemberian Teh Kombucha. Buletin Anatomi dan Fisiologi. Vol. XXIII, No. 1, hlm. 1-8. 